\title{
Therapeutic Interchange: New Initiative System in Saudi Arabia
}

Yousef Ahmed Alomi', BSc. Pharm, MSc. Clin Pharm, BCPS, BCNSP, DiBA, CDE, Critical Care Clinical Pharmacists, TPN Clinical Pharmacist, Freelancer Business Planner, Content Editor and Data Analyst, Riyadh, Saudi Arabia. Faiz Abdullah. Bahadig, R.Ph, Informatics Pharmacist, Pharmaceutical Care Department, King Abdul-Aziz Medical, City-WR-Jeddah, Ministry of National Guard, Saudi Arabia.

\section{Correspondence:}

Dr. Yousef Ahmed Alomi, BSc. Pharm, MSc. Clin Pharm, BCPS, BCNSP, DiBA, CDE, Critical care clinical pharmacists, TPN clinical pharmacist, Freelancer Business Planner, Content Editor and Data Analyst. P.O.BOX 100, Riyadh 11392, Riyadh, Saudi Arabia

Phone no: +966504417712

E-mail:yalomi@gmail.com
Received: 24-10-2019;

Accepted: 7-12-2019

Copyright: (C) the author(s), publisher and licensee International Journal of Pharmacology and Clinical Sciences. This is an open-access article distributed under the terms of the Creative Commons Attribution Non-Commercial License, which permits unrestricted non-commercial use, distribution, and reproduction in any medium, provided the original work is properly cited.

This is an open access article distributed under the terms of the Creative Commons Attribution-NonCommercial-ShareAlike 4.0 License

Access this article online

\begin{tabular}{|c|c|}
\hline & www.ijpcs.net \\
\hline & DOI: \\
\hline
\end{tabular}

\section{ABSTRACT}

Objective: To validate the therapeutic interchange system at healthcare institutions as new initiatives in the Kingdom of Saudi Arabia. Methods: It is a new initiative project drove by national therapeutic interchange system programs. The projects drove the therapeutic interchange system guidelines and the international business model, pharmacy project guidelines project management institution guidelines of a new project. The initiative project is written through project management professionals and contained of several parts, including the initial phase, the planning phase, the execution phase and the monitoring and controlling phase. Results: The therapeutic interchange services with a defined vision, mission and goals. The services had various aids, including clinical and economical, on patients and the healthcare system, as exemplified in the assessment. The continuation was of the project assured by the risk management model description. Besides, the monitoring and controlling of the services as declared. The transition to operation project, though closing the project stage, explored in the analysis. Conclusion: The therapeutic interchange system is a new initiative, part of the formulary management. There are various therapeutic interchange system classes of medications can be started though antibiotics, gastrointestinal medications and anti-psychiatric medications; it is highly recommended to implement in Saudi Arabia.

Key words: Therapeutic Interchange, Medications, Drug therapy, Initiative, System, Saudi Arabia.

\section{INTRODUCTION}

The role of the pharmacist is hypothetically active over yeas within clinical and economic outcomes in the Kingdom of Saudi Arabia. ${ }^{1-7}$ Besides, the pharmacy service used from primary inpatient outpatient pharmacy to clinical pharmacy services. $^{8-10}$ New advance pharmacy services founded, including Saudi managed care pharmacy and automated disposing and robotic system. ${ }^{11,12}$ Through the extension of pharmaceutical care services and including medications, multiple tools of formulary management to control drugrelated problems and any additional economic burden on the healthcare system. Among the tools used in formulary management is therapeutic interchange. ${ }^{13}$ The system can be change medications to the new one with the same of different molecules and the same safety and efficacy..$^{13}$ The therapeutic interchange system can keep the medications for all patients at all times in a cost-efficient manner. ${ }^{14}$ The system specified in several countries for more than 30 years and showed huge benefits at an appropriate cost. ${ }^{13-19}$ That is including several pharmacological groups of medications, for instance, but not limited to antibiotics, gastrointestinal medications, antipsychiatric medications, medication for asthma management and dermatology medications (Table 1). ${ }^{13-19}$ Multiple studies displayed the safety and efficiency of interchange medications and some had not showed. The aim of this review is to affirm the new initiative's program of therapeutic interchange project and implementation project management in the Kingdom of Saudi Arabia.

\section{Method of Development the Project}

The task force committee contained of expert people from the pharmacies of the various healthcare institutions to set up the therapeutic interchange system for applications for hospital's pharmacies, primary healthcare centers' pharmacies, dental centers' pharmacies and community pharmacies. The first author ruled the therapeutic interchange committee; they conducted regular periodical meetings. The committee unitized and drove the therapeutic interchange system from national and international literature. Besides, by using the international business model, pharmacy guidelines, project management institution guidelines of a new project, ${ }^{21-24}$ the committee members reviewed the draft. Then, the second draft was revised again by the committee members for their final comments and approval. The draft appropriated around 4-6 months to complete the task. The therapeutic interchange project consisted of several parts that are including; the initial phase, planning phase, execution phase, monitoring and controlling aspect.

\section{Initiative Phase \\ Assessment Needs}

The pharmacist works everyday to bring medications to all kinds of patients with various diseases, acute or chronic. The medications should be available 24/7 in the pharmacy and influence patients in the best and suitable procedures. A shortage of medications is a common problem that may harmfully affect 


\begin{tabular}{|c|c|c|c|c|c|c|c|c|}
\hline No. & Author & $\begin{array}{c}\begin{array}{c}\text { Year } \\
\text { of } \\
\text { publication }\end{array} \\
\end{array}$ & Country & $\begin{array}{c}\text { No. of } \\
\text { participants }\end{array}$ & Duration & $\begin{array}{l}\text { Study } \\
\text { design }\end{array}$ & Outcome & Comments \\
\hline 1 & $\begin{array}{c}\text { Oh, T } \\
\text { Franko, T G (15) }\end{array}$ & 1991 & USA & NA & 3 years & $\begin{array}{l}\text { observational } \\
\text { study }\end{array}$ & $\begin{array}{l}\text { The results should the impact of } \\
\text { the experience of the therapeutic } \\
\text { interchange services at one } \\
\text { hospital. The interchange list } \\
\text { medication is good }\end{array}$ & $\begin{array}{c}\text { The study was done in one } \\
\text { year. The net cost saving } \\
\text { not documented }\end{array}$ \\
\hline 2 & Carroll NV (16) & 2000 & USA & $\begin{array}{l}23 \\
\text { community } \\
\text { pharmacists }\end{array}$ & 24 Months & Cohort study & $\begin{array}{l}\text { Form a total of } 43,141 \\
\text { prescriptions, } 147 \text { of them had } \\
\text { done therapeutic interchanges } \\
\text { by the pharmacist with } 4.6 \\
\text { per } 1000 \text { prescriptions had } \\
\text { IT. Of that } 54.2 \% \text { approved } \\
\text { by physicians and patients. } \\
\text { Most of the medication had TI } \\
\text { was Respiratory-tract agents, } \\
\text { Antimicrobial agents and Pain } \\
\text { products. The average saving } \\
\$ 18.47 \pm \$ 40.99 \text { per each } \\
\text { prescription }\end{array}$ & $\begin{array}{l}\text { The study about the impact } \\
\text { of TI with the pharmacist. } \\
\text { the sample was low and } \\
\text { without clear protocol of } \\
\text { TI medication list }\end{array}$ \\
\hline 3 & $\begin{array}{c}\text { Eurich, D et al } \\
\text { (18) }\end{array}$ & 2001 & Canada & $\begin{array}{l}211 \text { director of } \\
\text { pharmacy }\end{array}$ & 2-3 month & cross s3ectyional & $\begin{array}{l}\text { Of the } 211 \text { hospitals } 186(88 \%) \\
\text { had a therapeutic interchange } \\
\text { program. } \\
\text { The most medication involved } \\
\text { were antibiotics, antacids } \\
\text { and adsorbents, replacement } \\
\text { preparations, miscellaneous } \\
\text { gastrointestinal drugs, vitamins } \\
\text { and cardiovascular drugs }\end{array}$ & $\begin{array}{l}\text { The study about the } \\
\text { pattern of Therapeutic } \\
\text { interchange } \\
\text { implementation } \\
\text { they had a good number } \\
\text { of the hospital without any } \\
\text { clear clinical or economic } \\
\text { outcomes }\end{array}$ \\
\hline 4 & $\begin{array}{l}\text { Schachtner, Jill } \\
\text { M et al. (14) }\end{array}$ & 2002 & USA & $\begin{array}{l}463 \text { Director } \\
\text { of hospital } \\
\text { pharmacy }\end{array}$ & & cross-sectional & $\begin{array}{l}\text { 89-100 \% of hospitals applied } \\
\text { TI. Most medication classes } \\
\text { were histamine H2 -receptor } \\
\text { antagonist, proton-pump } \\
\text { inhibitors, antacids and } \\
\text { quinolones }\end{array}$ & $\begin{array}{l}\text { The study about the } \\
\text { pattern impact of TI with } \\
\text { the pharmacist. The study } \\
\text { had a good number of } \\
\text { the hospital with cost- } \\
\text { saving. The cost-saving } \\
\text { per each prescription not } \\
\text { mentioned }\end{array}$ \\
\hline 5 & $\begin{array}{c}\text { Glaholt, S et al. } \\
\text { (19) }\end{array}$ & 2014 & USA & 47 & 6 month & $\begin{array}{l}\text { retrospective } \\
\text { chart review }\end{array}$ & $\begin{array}{c}\text { From } 317 \text { interventions Of } \\
\text { these, } 47 \text { patients (15\%) } \\
\text { ACE inhibitors followed by PPIs, } \\
\text { antidepressants, H2 receptor } \\
\text { and non-sedating } \\
\text { antihistamines }\end{array}$ & $\begin{array}{c}\text { The number of the patient } \\
\text { was few. The cost-saving } \\
\text { not documented }\end{array}$ \\
\hline
\end{tabular}

the patients and the sequencing of the disease. The pharmacist should implement an inventory management system to prevent any shortage of medications. Sometimes there various causes of shortage related to pharmaceutical companies. One of the excellent solutions for shortages of medications is therapeutic interchange. The new system well established external for a long time. The therapeutic interchange system had multiple clinical advantages for the patients and economic outcomes on the healthcare system. The demand is high overall Saudi Arabia during the implementation of the Saudi Managed care system and new pharmacy strategic of new Saudi vision 2030. ${ }^{11,24}$

\section{SWOT Analysis}

One of the famous used for the analysis of new projects is the SWOT tool. That has comprised strength, weakness, opportunity and threads. The most strength points for the current project are to prevent drug shortage for acute and chronic diseases, evasion of needless cost economic on the healthcare system and implemented the guidelines during health insurance companies.

The weakness points were not available alternatives medications, few sign of support therapeutic interchange system and the pharmacist need education and training about therapeutic interchange services. While opportunity points were the high shortage and medications and implementation of quality management guidelines; the thread points were absent of therapeutic interchange guidelines or policy and procedures expert and inattentive the expert pharmacy leaders during therapeutic interchange services at all healthcare institutions.

\section{Market Analysis}

The therapeutic interchange system might found at healthcare organizations during used generic medications as substitutes to patent medications or switch from intravenous medications to the oral dosage form. However, the 
therapeutic interchange by a switch from one medication to another molecule with the same pharmacological class does not occur. The new system was not implemented at most of the governmental or private organizations during regular days or mass gatherings hajj period. Besides, most healthcare services had almost the same system, either governmental or private institutions. The shortage of medications is a common problem at all the levels of healthcare institutions and a high claim for an excellent solution for the out of stock medications. Even though the therapeutic interchange system is an excellent preventive solution, however, it rarely implemented in the healthcare organization.

\section{Planning Phase}

\section{Scope of the Project}

The scope of the current project is the therapeutic interchange system, the vision and mission, the implementation phase and processes of monitoring parameters of the project until the change to the operating system at healthcare services in the Kingdom of Saudi Arabia. The vision to reach the best therapeutic interchange system with the best medications at healthcare organizations in Saudi Arabia. The mission they deliver best and high quality and appropriate cost management through the therapeutic interchange system at healthcare services. The goal of the project is to provide a list of medications as therapeutic interchange, to keep all medications available for patients $24 / 7$, to prevent drug-related problems with therapeutic interchange system medications and to avoid additional unnecessary cost on the healthcare system.

\section{Project Description}

Various international guidelines to implement therapeutic interchange in the practice; that including desiging therapeutic interchange, mediation clsses appropriate for therapeutic interchange and role of pharmacist in the system..$^{25-29}$ The author recommends the following policy and procedure for implemention as follows:

\section{All the pharmacists and health should be following policy}

- Annually, the healthcare give including the pharmacy staff update the medication list and interchange.

- The updated list should distribute to all healthcare provider.

- The pharmacist should check with all healthcare team of switching medication alternatives.

- The annual education course deliver to the healthcare teams.
- $\quad$ The pharmacist should notify the treating physician to fill the form (appendix 1) of Therapeutic Interchange to agree with signature the alternatives due to the presented reasons.

- The pharmacist should educate the patient about interchange medication.

- The caregiver should notify his/her supervisor or department director/head as soon as possible after the occurrence or discovery of the medication error during therapeutic interchange and if the occurrence is severe, take immediate action.

- The immediate supervisor or employer must be notified to assess the outcome and to take action.

- The patient shall be monitored for unwanted drug-related problems and patient satisfaction of medication interchange. ${ }^{1}$

- $\quad$ All drug-related problems after interchange medications should be documented..$^{30-32}$

- All therapeutic interchange forms immediate supervisor or employer should sign and forward it to the pharmacy department.

- The following information in the drugrelated problems during therapeutic interchange form must be documented by Medication Safety Officer (MSO) or document by the pharmacist or pharmacy technician; then the form had been sent to MSO at the pharmacy department.

- Medication safety officer at the pharmacy department should document his/her suggestions to prevent recurrence of error based on his/her assessment of the action taken, a document that and sign the drug-related problems and therapeutic interchange form.

- The clinical pharmacy department and medication safety officer is responsible for gathering the data of all the therapeutic interchange drug-related problems reporting reported and formulate an annually.

- An investigation of the therapeutic interchange medication errors causes and contributing factors should be performed and documented by the medication safety officer in coordination by the affected department(s)/assigned team, or Root Cause Analysis (RCA) investigation if the case is measured as a sentinel event.

- Necessary action(s) should be taken with follow-up as necessary to decrease reoccurrence and to prevent medication error occurrence with therapeutic interchange.

- The therapeutic interchange policy should update frequently based on the drugrelated problem, patient satisfaction and cost-saving of using alternative medications.

\section{Plan Cost Management}

The financial budget of the project desires to be proposed. The education and training therapeutic interchange course for the management team and all healthcare providers, including the pharmacy staff, the cost of update resources for therapeutic interchange guidelines and the cost of a management team for monitoring the project. The budget desires close monitoring by the management team overall, the period of implementation.

\section{Executing Phase Management Team}

The management team accountable for follow-up on the Therapeutic Interchange was pharmacy administration and leadership with corporate pharmacy and therapeutic committee. The central committee planned though the pharmaceutical care administration at healthcare institutions, the committee contained of representatives from each region specialized in clinically pharmacy oriented with an emphasis on therapeutic interchange. Another regional committee recognized for each region consisted of representatives from each hospital and group primary care center. Each hospital or group of primary care centers established a local pharmacy and therapeutic committee. The local committee contained of a clinical pharmacist, physician, nurses, quality management, risk management and any invited member. All committees have a regular meeting to discuss the pharmacy and therapeutic and documentation, therapeutic interchange analysis, medications error analysis during therapeutic interchange and cost-saving as the impact of therapeutic interchange. ${ }^{33}$

\section{Education and Training}

The therapeutic interchange system project desires several education courses for clinical pharmacists and dispensing pharmacists. Besides, orientation therapeutic interchange education courses for healthcare providers, including physicians and nurses. The management team needs therapeutic interchange education and training sessions. The clinical and economic outcome of therapeutic interchange services education session for all healthcare providers sometimes at all level of healthcare institutions.

\section{Monitoring and Controlling Phase Project Total Quality Management}

The famous procedure used for total quality management within the application of the therapeutic interchange project was the Balanced Scored Card. It contained four parts that are including the customer, finance, internal process, education and innovation. The internal processes part contained the assessment of healthcare services of the therapeutic interchange. 
Besides, the education and innovation par was the measures of clinical outcomes for therapeutic interchange that's replicated the education and competency of clinical pharmacists and distributed pharmacists. One the other hand, the financial elements had the measurement of economic saving of the therapeutic interchange system. The fourth part contained the customer section that measures the patient's satisfaction on therapeutic interchange or healthcare providers and pharmacy staff satisfaction of therapeutic interchange in the Kingdom of Saudi Arabia. ${ }^{34,35}$

\section{Risk Management}

There are six types of risk management included budget risk, scope risks, personal risks, schedule risk, technical risks and quality risks. Most of the risks that may be uncovered will be budget, personal, schedule risk and quality risks. The budget risk related to nonavailable enough budget for education and training for the project, there is not enough budget to update the medication list and interchange system. The project may expose to personal risks that the human resources of pharmacy not available and shortage of staff with the high capacity of therapeutic interchange; the healthcare staff did not follow the regulation of therapeutic interchange and maybe the patient refuses the alternatives medications. Besides, the healthcare and pharmacy staff not established education or training about the project. Schedule risk that included maybe the program not started during physician rejection and resistance to implementing. The quality risks may be exposed to it due to nonqualified pharmacists available and training in the quality pharmacy tools. Other technical risks may expose to the projects with the nonavailable electronic system of medication list or interchange drug implementation and documentation with approachable use.

\section{Closing of the Project}

The therapeutic interchange system at all healthcare organizations of the governmental and private sectors are highly suggested to prevent a shortage of medications, patient's illness management speedily and avoid the additional needless cost in the Kingdom of Saudi Arabia. The project should continue at the therapeutic interchange at each pharmacy department, healthcare services and related committees. Education and training for therapeutic interchange should be performed occasionally. Besides, therapeutic interchange medications should update with the extension number of medications in the future. The therapeutic interchange system should conduct the annual celebrate that is highly suggested in Saudi Arabia.
ACKNOWLEDGMENT

None.

\section{CONFLICT OF INTEREST}

None.

\section{ABBREVIATIONS}

MOH: Ministry of Health; KSA: Kingdom of Saudi Arabia; RCA: Root Cause Analysis; SWOT: Strengths, Weakness, Opportunities and Threats; PTC: Pharmacy and Therapeutics Committee; MSO: Medication Safety Officer.

\section{ORCID ID}

Yousef Ahmed Alomi https://orcid.org/00000003-1381-628X

\section{REFERENCES}

1. Alomi YA, Fallatah AO, Bahadig FA, et al. The economic outcomes of pharmacist interventions in total parenteral nutrition services in Saudi Arabia. Pharmacol Toxicol Biomed Reports. 2019;5(3s):S40-9.

2. Alomi1 YA, Fallatah AO, Al-Shubaar N, et al. The clinical outcomes of pharmacist interventions in total parenteral nutrition services in Riyadh City, Saudi Arabia. Int J Pharm Heal Sci. 2019;2(2):135-40.

3. Alanazi1 AA, Alomi YA, Almaznai MM, et al. Pharmacist's intervention and medication errors prevention at pediatrics, obstetrics and gynecology hospital in East Province, Saudi Arabia. Int J Pharm Heal Sci. 2019;2(2):122-8

4. Alomi YA, Alanazi MA, Alattyh RA, et al. Costefficiency of medication safety program at public hospital, Riyadh, Saudi Arabia. Pharmacol Toxicol Biomed Reports. 2019;5(3s):S4-8.

5. Alomi YA, Alanazi AA, Almaznai MM, et al. Costeffectiveness analysis of medication safety program at pediatrics, obstetrics and gynecology hospital, East Province, Saudi Arabia. Pharmacol Toxicol Biomed Reports. 2019;5(3s):S12-6.

6. Alomi YA, Aldosori N, Alhadab M, et al. The value of clinical pharmacist consultation visits at ministry of health hospitals in Saudi Arabia: Intravenous admixture services and pharmacy total quality management. J Pharm Pract Community Med. 2017;3(3).

7. Alomi YA, Aldosori N, Alhadab M, et al. The outcomes of clinical pharmacist consultation visits at ministry of health hospitals in Saudi Arabia: Medication safety and pharmacy research. J Pharm Pract Community Med. 2017;3(3).

8. Alomi YA, Jamaan Alghamdi S, Abdullah Alattyh R, et al. National survey of pharmacy practice at MOH hospitals in Saudi Arabia 2016-2017: Preparation of medications and dispensing. J Pharm Pract Community Med. 2018;4(1s):s54-9.

9. Alomi YA, Alghamdi SJ, Alattyh RA. National survey of pharmacy practice at $\mathrm{MOH}$ hospitals in Saudi Arabia 2016-2017: Clinical pharmacy services. J Pharm Pr Community Med. 2018;4(1):1S-8S.

10. Alomi YA, Shorog E, Alshahrani A, et al. National survey of pharmacy practice at $\mathrm{MOH}$ hospitals in Saudi Arabia 2016-2017: Drug monitoring and patients education. J Pharm Pract Community Med. 2018;4(1s):s17-22.

11. Alomi YA, Alghamdi SJ, Alattyh RA. Saudi Managed Care Pharmacy (SMCP): New initiative system of $\mathrm{MOH}$ prescriptions dispensed through community pharmacies. J Pharm Pract Community Med. 2017;3(3):145-53.

12. Alomi YA, Alghamdi SJ, Alattyh RA. National survey of pharmacy practice at $\mathrm{MOH}$ hospitals in Saudi
Arabia 2016-2017: Pharmacy computerized and technology. J Pharm Pract Community Med. 2018;4(1s):s40-6.

13. Carroll NV. Formularies and therapeutic interchange: The health care setting makes a difference. Am J Heal Pharm. 1999;56(5):467-72.

14. Schachtner JM, Guharoy R, Medicis JJ, et al. Prevalence and cost savings of therapeutic interchange among U.S. hospitals. Am J Heal Pharm. 2002;59(6):529-33.

15. Oh T, Franko TG. Comprehensive therapeutic interchange program in a community hospital. Am J Hosp Pharm. 1991;48(7):1471-7.

16. Carroll N V. Therapeutic interchange in community pharmacies in Virginia. Am $\mathrm{J}$ Heal Pharm. 2000;57(9):882-6.

17. Wang JS, Fogerty RL, Horwitz LI. Effect of therapeutic interchange on medication reconciliation during hospitalization and upon discharge in a geriatric population. PLoS One. 2017;78:1-11.

18. Eurich D, Poulin S, Semchuk W, et al. Therapeutic interchange in Canadian hospitals: A national survey. Can J Hosp Pharm. 2001;54(28-34).

19. Glaholt S, Hayes GL, Wisniewski CS. Evaluation of discharge medication orders following automatic therapeutic substitution. P\&T® ${ }^{\circledR}$. 2014;39(4):267-77.

20. McDonough R. Writing a business plan for a new pharmacy service. The Dynamics of Pharmaceutical Care: Enriching Patients' Health. 2010;23.

21. Harris IM, Baker E, Berry TM, et al. Developing a business-practice model for pharmacy services in ambulatory settings. Pharmacotherapy. 2008; 28(2):7e-34e

22. Sachdev G. Sustainable business models: Systematic approach toward successful ambulatory care pharmacy practice. Am J Heal Pharm. 2014; 71(16):1366-74.

23. PMBOK Guide. A guide to the project management body of knowledge. Sixth Edition. Project Management Institute, Inc., 2017.

24. Alomi YA. New pharmacy model for vision 2030 in Saudi Arabia. J Pharm Pract Community Med. 2017;3(3).

25. Mills EJ, Gardner D, Thorlund K, et al. A users' guide to understanding therapeutic substitutions. J Clin Epidemiol. 2014;67(3):305-13.

26. Gray T, Bertch K, Galt K, et al. Guidelines for therapeutic interchange. Pharmacotherapy. 2005;25(11):1666-80.

27. Wall DS, Abel SR. Therapeutic-interchange algorithm for multiple drug classes. Am J Heal Pharm. 1996;53(11):1295-6.

28. Holmes DR, Becker JA, Granger CB, et al. ACCF/ AHA 2011 health policy statement on therapeutic interchange and substitution. Circulation. 2011;124(11):1290-310.

29. Compendium AMAP, Vol HP, Ama T. AMA policy on drug formularies and therapeutic interchange in inpatient and ambulatory patient care settings. Am J Hosp Pharm. 1994;51(14):1808-10.

30. American Society of Hospital Pharmacists. ASHP guidelines on preventing medication errors in hospitals. Am J Hosp Pharm. 2018;75:1493-517.

31. Ling JM, Mike LA, Rubin J, et al. Documentation of pharmacist interventions in the emergency department. Am J Heal Pharm. 2005;62(17):1793-7.

32. Mutnick AH, Sterba KJ, Peroutka JA, et al. Cost savings and avoidance from clinical interventions. Am J Heal Pharm. 1997;54(4):392-6.

33. Alomi YA. National medication safety program at ministry of health in Saudi Arabia. J Pharmacovigil. 2015;3(5):e145

34. Alomi YA, Alghamdi SJ, Alattyh RA. Strategic plan of general administration of pharmaceutical care at ministry of health in Saudi Arabia 2012 - 2022 J Pharm Pharm Scien. 2015;1(13):1-8.

35. AlomiY. National pharmacy administration programs. BAOJ Pharm Sci. 2015;1(2):1-2. 